\title{
Misconception and Effect of Menstruation (Chhaupadi) and Delivery on Women's Health in Bajura, District Nepal
}

Chetraj Pandit ${ }^{1}$, Anil Kumar Singh ${ }^{2}$, Ayuska Parajuli ${ }^{3}$, Ashok Pandey ${ }^{4}$

Author Info:

${ }^{1}$ Health worker, Family Welfare Division, Department of Health Services Teku Kathmandu, MoHP Nepal.

${ }^{2}$ Assistant professor, Institute of Medicine, Maharajgung

Kathmandu, Tribhuwan

University, Nepal.

${ }^{3}$ Qualitative Research Officer, Herd International, Thapathali, Kathmandu, Nepal.

${ }^{4}$ Senior Research Officer, Nepal Health Research Council Ramshapath Kathmandu, Nepal

\section{Corresponding Author:}

Ashok Pandey

Email/Contact:

ashok1pande@gmail.com ORCID: https://orcid. org/0000-0001-8471-1253

\section{ABSTRACT}

Background: Chhaupadi is the old unscientific system in mid and far western parts of Nepal. Reproductive age women were considered unclean during the menstrual and delivery period. Invisible cultural taboos and practices were prevailing in each and every household. The objective of the study is to assess the associated factors affecting during Chhaupadi and delivery practice with their health outcome.

Method: The cross-sectional descriptive study was conducted amongst 175 reproductive age women in Bajura districts of Nepal, by using multistage random sampling. Both qualitative and quantitative methods was used. All the data were entered in Ms excel and exported into SPSS 16.0. The necessary descriptive and inferential statistics was used for quantitative analysis and thematic analysis was done for qualitative analysis.

Results: More than one third (38.9\%) of the participants were in the age group 20-29 years. Almost all the participants were from Hindu religion. The majority (91\%) of participants know about the Chhaupadi system. Almost (74\%) of the participants were staying in the Chhaupadi hut during menstruation. Similarly, (78.3\%) of the respondents were mentioned, they did not like the Chhau system and never like to continued. There is a significant association between health effect in women and the Chhaupadi system $(p<0.031)$.

Conclusion: We conclude that the larger proportion of women in Bajura District still believes in old unscientific tales and Chhaupadi practices which lead to the different health problems.

Keywords: Chhaupadi practices; Menstruation Misconception; Women's Health.

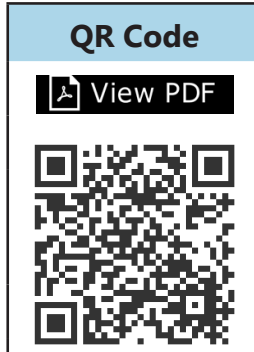

Scan Me

\section{Article Info}

Received: 11 December 2020; $\quad$ Accepted: 27 February 2021;

Published Online: 27 February 2021 How to cite this article in Vancouver Style?

Pandit C, Singh AK, Parajuli A, Pandey A. Misconception and effect of Menstruation (Chhaupadi) and Delivery on Women's Health in Bajura, District Nepal. Europasian J Med Sci. 2021:3(1):24-29. https://doi.org/10.46405/ejms. v3i1.123

\section{Disclaimer}

Conflict of Interest: None Declared;

Source of Support: Nil

Copyright (C) 2021 by author(s). This work is licensed under the terms and condition of Creative Commons Attribution International License 4.0@ (1) (http://creativecommons.org/licenses/by/4.0/) which permits unrestricted use, distribution, and reproduction in any medium, provided the original work is properly cited. This is an open access publication, and can be downloaded freely from the website of the Journal: www.europasianjournals.org. The Journal as well as publisher remain neutral with regards to any jurisdictional claims in any published articles, its contents and the institutional affiliations of the authors. The Europasian Journal of Medical Sciences (EJMS) (www.europasianjournals.org) is an official Journal of Nirvana Psychosocial Care Center \& Ressearch Institute (www.nirvanapscc. com). 


\section{INTRODUCTION}

Menstruation is a variable pattern within a few years of menarche which may not be well understood by many adolescent girls. ${ }^{1}$ Menstruation is a series of events, occurring in females every 26 to 30 day throughout the childbearing period of about 36 years. ${ }^{2}$ The cycles consist of a series of change that takes place concurrently in the ovaries and uterine wall, stimulated by a change in the blood concentration of hormones. ${ }^{3}$ Menstruation-related misconceptions are still prevailing in the far west and mid-west developmental region of Nepal. Reproductive age women should have to stay outside the home called Chhau Goth for at least 4 to 5 days. ${ }^{4}$ They were not allowed to touch the male person, cultivated land, plants, etc., ${ }^{2,5}$ In the developed nations, women assume menstrual periods is the part of their private lives and will not affect their ability to work, go to school or otherwise they can contribute to society work. ${ }^{6}$ As opposed to the statement, women are considered unclean during the menstrual period in Nepal. ${ }^{2}$ During the menarche, Hindu adolescent girls have to keep in a dark room for four to sixteen days and are forbidden to see the sun.? During this period of seclusion, she is often guarded by her relatives. She is not allowed to speak or if necessary, it should be not above a whisper. ${ }^{8}$

The menstrual huts were built in the ancient period and patriarchal societies in Nepal. ${ }^{4}$ Menstrual huts are associated with ideas of pollution, misogyny, and inter-sexual tension known variously as "Chhue" in Dadeldhura District, "Chhaupadi" in Achham and Bajura District and "Chueekula" in Humla district.2, ${ }^{2,10}$ During menstruation and delivery, women must stay in a small shed called Chhau Goth. ${ }^{4,11}$ Although there are differences in menstruation and delivery by nation and within a nation on customs, culture, beliefs, ethnic group, social class or family. ${ }^{12-14}$ Menstruationrelated myths, misconceptions, superstitions and taboos concerning menstrual blood and menstrual hygiene is the subject of thinking from researcher and policy makers in Nepal. ${ }^{1,15-18}$

\section{MATERIALS AND METHODS}

The mixed method were used to carry out the misconception and its effects by Chhaupadi in Bajura districts. 15-49 years old reproductive age women were taken as the sample population from Jugada village development committee (VDC). For selecting the sample size, all the 27 VDCs was listed, among them, Jugada VDC was selected for the study. In the second stage, ward number 3, 4 and 5 were selected randomly out of 9 wards. All the reproductive age women were listed and by using systemic random sampling 175 women was selected by assuming the prevalence of women practicing Chhaupadi as $72 \%$ as per studies quoted under reference, and allowing a margin of error for estimating this rate as $10 \%$, sample size calculated by formula $n=4 p q / L 2$ was 160 . Allowing a nonresponse rate of $10 \%$, about 175 women were included for the study. The tools of data collection of this study were the questionnaire.

Focus group discussion (FGD) was done with 18 participants who were practicing Chhaupadi practice at the same location. Key In-depth Interviews (KII) were done with 5 key stakeholders of the Jugada VDC which was selected by following the theory of saturation. Qualitative data were collected using FGD guidelines and necessary transcribing coding, and analysis was done using the thematic analysis technique manually.

The social and cultural values of the research participants have maintained by stating the research participants under anonymity and confidentially situation. The validity and reliability of the tool maintained by pre-test in the similar settings. Data collection was done by researcher themselves from August to October 2014. The socio-demographic factors like religion, marital status, caste, and family size were done analyzed through the crosstabulations. The bivariate and multivariate analysis were done for assessing the association of cultural practices and effect of women's health.

\section{RESULTS}

The mean age of participants was $28 \pm 8.71$ (Mean \pm S.D) 28 years. The majority $(60 \%)$ of the respondents were from the Chhetri caste followed by Dalit $24 \%$. The majority (81.1\%) of the participants were involved in agriculturist followed by students (16\%), services. Almost all (175 out of 175) were belonged to families practicing Hinduism. Regarding the education, literary rate was just one third only (31.4\%). (Table 1)

There is not association between knowledge on Chhaupadi system and its effect in women health $(P>0.196)$. In fact, majority $(80.5 \%)$ of the participants have knowledge on chhaupadi system. (Table 2)

\section{Perception about the Chhaupadi}

The majority (74\%) of the participants were staying 


\begin{tabular}{lll}
\hline \multicolumn{3}{l}{ Table 1. Socio-demographics characteristics $(\mathrm{n}=175)$} \\
\hline Characteristics & Frequency & Percent (\%) \\
\hline Ethnicity & & \\
Brahmin & 26 & 14.8 \\
Chhetri & 105 & 60.0 \\
Newar & 1 & 0.6 \\
Janajati & 1 & 0.6 \\
Dalit & 42 & 24.0 \\
\hline Occupation & & \\
\hline Agriculture & 142 & 81.1 \\
Services & 4 & 2.3 \\
Business & 1 & 0.6 \\
Student & 28 & 16.0 \\
\hline Types of family & & \\
\hline Nuclear & 34 & 19.4 \\
Joint & 133 & 76.0 \\
Extended & 8 & 4.6 \\
\hline Income & & \\
\hline Agriculture & 165 & 94.3 \\
Business & 5 & 2.9 \\
Foreign services & 2 & 1.1 \\
Labor & 1 & 0.6 \\
Others & 2 & 1.1 \\
\hline & & \\
\hline & & \\
\hline & & \\
\hline
\end{tabular}

in the Chhaupadi Goth (hut) for 5 days during menstruation. Among them, more than 9 out of 10 (91\%) participants have no more toilet facilities. They defecate, bathing and washing in the open place. Very few (3\%) of the participants mentioned the distance between house to Chhaupadi Guth takes more than 5 minutes whereas majority $(89 \%)$ mentioned less than 1 minute. Maximum 8 out of 10 (78\%) of the participants in the Chhaupadi system. They mentioned the different effects like health effects (37\%), physical violence $(31 \%)$ and feeling alone (10.9\%) respectively. Similar findings were show by FGD and key in-depth results;

"I used to stay in the Chhau Goth (separate Mensturation hut) during menstruation for 5 days. I feel scared of wild animals including domestic dogs. Bad smell of domestic animals is another challenges. I obliged to give the milk and dairy products to me. My family members considered me as the unclean and impure. This is the fate of women... what can I do?"

- 30 years old women from Jugada, Bajura

Menstrual women were supposed to secular during menstruation time. They never allow touching the fruit tree, fetching the water, plants or milking the cattle. It is believed that if they touch the fruit trees, the fruits can fall down before ripening or decayed; if they fetch water unknowingly, the well may be

Table 2. Knowledge on Chhaupadi system and effect in women health $(n=138)$

\begin{tabular}{|c|c|c|c|c|c|c|c|c|c|c|}
\hline \multirow{3}{*}{$\begin{array}{l}\text { Knowledge on } \\
\text { Chhaupadi system }\end{array}$} & \multicolumn{8}{|c|}{ Effect on women's health } & \multirow{3}{*}{$\begin{array}{l}\chi^{2} \\
\text {-value }\end{array}$} & \multirow{3}{*}{$P$ - value } \\
\hline & Yes & & No & & Don't & know & Tota & & & \\
\hline & No & $\%$ & No & $\%$ & No & $\%$ & No & $\%$ & & \\
\hline Yes & 128 & 80.5 & 12 & 7.5 & 19 & 11.9 & 159 & 100 & & \\
\hline No & 10 & 62.5 & 3 & 18.8 & 3 & 18.8 & 16 & 100 & $3.261^{* *}$ & $0.196^{*}$ \\
\hline
\end{tabular}

Table 3. Association between believes on Chhaupadi system and effect in women health

\begin{tabular}{|c|c|c|c|c|c|c|c|c|c|c|c|}
\hline \multirow{3}{*}{\multicolumn{2}{|c|}{$\begin{array}{l}\text { Reasons for believing in } \\
\text { Chhaupadi system }\end{array}$}} & \multicolumn{8}{|c|}{ Effect in women health } & \multirow[t]{4}{*}{$\chi^{2}$-value } & \multirow[t]{4}{*}{$\mathrm{P}$ - value } \\
\hline & & \multicolumn{2}{|c|}{ Effect } & \multicolumn{2}{|c|}{ No effect } & \multicolumn{2}{|c|}{ Don't know } & \multicolumn{2}{|c|}{ Total } & & \\
\hline & & No. & $\%$ & No. & $\%$ & No. & $\%$ & No. & $\%$ & & \\
\hline \multirow[t]{2}{*}{ Culture } & Yes & 43 & 78.2 & 2 & 3.6 & 10 & 18.2 & 55 & 100 & & \\
\hline & No & 95 & 79.2 & 13 & 10.8 & 12 & 10.0 & 120 & 100 & $4.29 * \star$ & 0.117 \\
\hline \multirow[t]{2}{*}{ Religion } & Yes & 45 & 91.8 & 2 & 4.1 & 2 & 4.1 & 49 & 100 & & \\
\hline & No & 93 & 73.8 & 13 & 10.3 & 20 & 15.9 & 126 & 100 & $6.95^{\star *}$ & $0.031^{*}$ \\
\hline \multirow{2}{*}{ Taboos } & Yes & 48 & 94.1 & 2 & 3.9 & 1 & 2.0 & 51 & 100 & & \\
\hline & No & 90 & 72.6 & 13 & 10.5 & 21 & 16.9 & 124 & 100 & $10.38^{* *}$ & $0.006^{*}$ \\
\hline \multirow[t]{2}{*}{ Society } & Yes & 50 & 76.9 & 8 & 12.3 & 7 & 10.8 & 65 & 100 & & \\
\hline & No & 88 & 80.0 & 7 & 6.4 & 15 & 13.6 & 110 & 100 & $2.00^{* *}$ & 0.268 \\
\hline
\end{tabular}


Table 4 Association between the Chhaupadi system and Effect in women health $(n=138)$

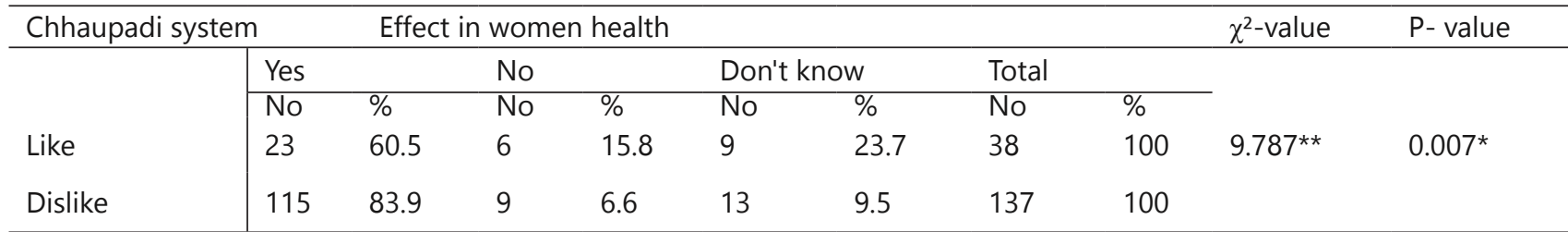

dry up; if the cattle are fed or milking, blood comes out instead of milk. There is significant association between health effect in women and the religion $(p<0.031)$ and the taboos $(p<0.006)$. This also shows, reproductive women on this districts were not happy with the Chhaupadi tradition. (Table 3)

\section{Chhaupadi system during menstruation}

The majority (79\%) of the participants reveals the Chhaupadi system had a harmful effect on the health of women. The effect includes physical harms (75\%), hemorrhage (54\%) Infections (32\%), suffering from cold (21\%), Anemia (13\%), abdominal pain $(5 \%)$, pelvic inflammatory disease diseases (PID) (5\%) and fever (3\%). Similarly, more than one third (35\%) participants mentioned different mental health effects also. There is the significant association between Chhaupadi system and effect in women health $(p<0.007)$. (Table 4)

The large majorities (95\%) participants were restricted on consuming varieties during menstrual period staying in Chhau Goth. Among them almost 9 out of 10 (89\%) participants were restricted on taking the milk, (54.4\%) dairy products, (32\%) access on food, (16\%) on meat and (8\%) green leafy vegetable respectively.

\section{Chhaupadi system during delivery}

The large majority (92\%) of the participants were staying in the Chhau Goth (delivery hut) during delivery time. The day for staying in the Chhau Goth is range from day to month. Almost 9 out of $10(89 \%)$ of the participants reveals the distance between home to Chhau Goth is less than 1 minute and only (2\%) participants said more than 5 minutes. Almost half (49\%) of the participants reveals traditional birth attendance (TBA) assisted during the delivery time and significantly low only (11\%) pregnant delivered by themselves. This is the real situation of the Chhaupadi system in Bajura and western Nepal. Without assistance, many pregnant women were born their baby in the house or even in the field where they work.

The large majority (93\%) participants feeling health effect due to Chhau Goth delivery. The range of health difficulties are bleeding (56\%), lack of care
(34\%), infection to mothers (31\%) and infection to infant (30\%). There is significant association between chau Goth delivery and effect in women health $(p<0.037)$.

"The pregnant women are secluded in a darkened section of the Chhau Goth. During winter and rainy season, there is very cold. Even though, I am not breaking the traditions to date."

\section{- $\quad$ FGD participants (Recently delivered} women) of Jugada

The large majority (95\%) of the participants were facing food restriction during delivery. The restricted food was range from milk (89\%), dairy products (54\%), meat (16\%) meat and green leafy vegetable $(8 \%)$ respectively.

\section{Improvement of Chhaupadi system}

9 out of 10 (90\%) participants want to improvements in the Chhaupadi system. The major source for changing the practice the Chhaupadi system is by school education (67\%), health education (63\%), trained traditional healer (24\%) and Mass campaign (20.6\%) respectively.

\section{DISCUSSION}

The mean duration of staying in Chaut goth is 5 days which compares with the mean duration of 4.9 days in Ghana. ${ }^{19}$ The large majority of participants did not like Chhaupadi system which is similar finding with the study conducted in the far western districts of Nepal.9,20 The majorities of participants shared Chaupadi system is the social taboos 15 These findings are similar to study conducted in West Bengal, India ${ }^{8}$ where many participants faced the certain restriction or taboo during menstruation. The Chhaupadi system effect on health of women, which is similar to the findings done by ${ }^{2}$ in Kathmandu, Nepal. The study revealed that food restriction during pregnancy and delivery time the study of Pondicherry, India. 21,22 Showing $67.7 \%$ avoided some vegetables/fruits, this data shows that majorities of women facing food restriction during pregnancy and delivery time. . $^{13,23,24}$ Furthermore, girls reported in FGD that they were worried about menstrual cycle relating problems. 
Many of the girls were more likely to report an absence from school during the menstruation because of various problems such as cramping, teasing, abdominal pain, fatigue, backache, and blood leaks. Also, they were anxious about leakage concentration, affected mood, and engagement in the class. ${ }^{7,17}$ So, due to these frequent menstrual problems, girls were used to absenting the school during menstruation. ${ }^{11,25}$ In contrast, several studies in low and middle income-countries reported similar findings on the participation of girls in school activities during their periods. ${ }^{14}$ The study showed that daily activities such as emotional distress, missed meal, inability to sleep, and need prolong rest were due to menstrual problems. The results of this study were consistent with those carried out by other researchers.

In this study, majorities of respondent think that menstrual hygiene means daily bathing that is $77.9 \%$ followed by change cloths $23.3 \%$, personal hygiene $18.8 \%$ and use sanitary pads only $17.5 \%$ respectively while $17.5 \%$ of the women in this study used sanitary pads as menstrual absorbents; this is very low $32.7 \%$ to the observation of in Nigeria 10 and $82.3 \%$ in West Bengal, India, 32\% Gujarat, India. ${ }^{26}$ It was observed that the this figure is surprising lower than Nigeria and India may be due to low availability of sanitary pad, high cost, religious and taboos factors but in relation to use of cloths as sanitary pads was $41.1 \%$, i.e. is very high $15.7 \%$ compare to study conducted by Shamima Yasmin et al in West bangal India, In relation to daily bathing $77.9 \% \%$ this is little lower than West Bengal, India $85.7 \% .^{27}$

\section{CONCLUSION}

Women are considered unclean during the menstrual period and are secured from many normal aspects of their lives. There are not any clear cultural and social reason for these taboos and practices prevailing in the community. Majority of participants fell the Chhaupadi system had a negative effect on the health of women. The larger proportion of women still believes in old unscientific tales, which lead to different healthrelated problems. From the study, we concluded that there is a need for education and awareness generation programs and orientation to all the people.

\section{Acknowledgments}

The authors are very grateful to Rajiv Gandhi University of Health Sciences for research support and the participants of this research study. The authors are also very thankful to Prof. NSN Rao, Mr. Arjun Neupane and Mr. Laxman KC for support on concept development and their unreserved support for this study.

\section{REFERENCES}

1. Juyal R, Kandpal SD, Semwal J. Social aspects of menstruation related practices in adolescent girls of district Dehradun. Vol. 25, Indian Journal of Community Health. 2013. p. 213-6. [Full text]

2. Pandey A. Challenges Experienced by Adolescent Girls while Menstruation in Kathmandu, Valley: A Qualitative Study. Journal of Community Medicine \& Health Education. 2014;04(03):41-5. https://doi. org/10.4172/2161-0711.1000285 [Full text]

3. Sapkota D, Sharma D, Pokharel HP, Budhathoki SS, Khanal VK. Knowledge and practices regarding menstruation among school going adolescents of rural Nepal. Journal of Kathmandu Medical College. 2014;2(3):122-8. https://doi.org/10.3126/jkmc. v2i3.9962, [Full text]

4. Dahal B, Acharya S, Munakarmi R, Sunar T, Parajuli B. A Study on effects of Chhaupadi Practices on Education of Adolescents Girls in Karnali. 2017. [Full text]

5. Wateraid. Is menstrual hygiene and management an issue for adolescent school girls? A comparative study of four schools in different settings of Nepal. Kathmandu; 2009. [Full text]

6. Pandey A, Mahotra NB. A comparative study of menstrual hygiene issues between public and private school going adolescent girls in Kathmandu Valley. JMMIHS. 2019;5(1):14-6. https://doi. org/10.3126/jmmihs.v5i1.24067, [Full text]

7. Pandey A, Subrimanium U, Tandan M, Panta M, Pandey M. Knowledge and Practices of Menstrual Hygiene among Adolescent girls in Kathmandu, Valley. In: Kumar S, Patil RR, Gopichandran V, editors. Public Health Research Series, Global Public Health Conference 2014 Proceedings. Chennai: SRM University; 2014. p. 33-9.

8. Yasmin S, Manna N, Mallik S, Ahmed A, Paria B. Menstrual hygiene among adolescent school students: An in- depth cross-sectional study in an urban community of West Bengal, India. IOSR Journal of Dental and Medical Sciences. 2013;5(6):22-6. [Full text]

9. Yadav RN, Joshi S, Poudel R, Pandeya P. Knowledge, Attitude, and Practice on Menstrual Hygiene Management among School Adolescents. J Nepal Health Res Counc. 2017;15(3):212-6. [Pubmed]

10. Sapkota D, Sharma D, Budhathoki SS, Khanal VK, Pokharel HP. Knowledge and practices regarding 
menstruation among school going adolescents of rural Nepal. Journal of Kathmandu Medical College. 2013;2(3):117-21. [Full text]

11. Kadariya S, R. Aro A. Chhaupadi practice in Nepal \&ndash; analysis of ethical aspects. Medicolegal and Bioethics. 2015;53. [Full text]

12. Abay Fisseha M. Menstrual Hygiene Practice and Associated Factors among Secondary School Girls in Wegera District, Northwest Ethiopia; a Cross-Sectional Study. Computational Biology and Bioinformatics. 2017;5(1):6. [Full text]

13. Biza Zepro N. Food Taboos and Misconceptions Among Pregnant Women of Shashemene District, Ethiopia, 2012. Science Journal of Public Health. 2015;3(3):410. [Full text]

14. Thakre SB, Thakre SS, Ughade S, Thakre AD. Urban-rural differences in menstrual problems and practices of girl students in Nagpur, India. Indian Pediatrics. 2012;49(9):733-6. [Full text]

15. Valvaikar K, Shah H. An urban-rural comparison of menstrual pattern and menstrual problems among school-going girls. International Journal of Medical Science and Public Health. 2016;5(10):2086. DOI: 10.5455/ijmsph.2016.29022016429, [Full text]

16. Sharma N, Sharma P, Sharma N, Wavare RR. A cross sectional study of knowledge, attitude and practices of menstrual hygiene among medical students in north India. The Journal of Phytopharmacology 2013; 2013;2(5):28-37. [Full text]

17. Thakre SB, Thakre SS, Reddy M, Rathi N, Pathak K, Ughade S. Menstrual Hygiene : Knowledge and Practice among Adolescent School Girls of Saoner, Nagpur District. Journal of Clinical and Diagnostic Research. 2011;5(5):1027-33. [Full text]

18. Regmi PR, Simkhada P, van Teijlingen ER. There are too many naked pictures found in papers and on the net: Factors encouraging premarital sex among young people of Nepal. Health Science Journal. 2010;4(3):169-81. [Full text]

19. Bruit G. Menstruation and Girls ' Education in
Northern Ghana. 2013;(August):1-109. [Full text]

20. Rh C, Acharya R, Shrestha N, Br G, Bb B, Kayastha M. Bacteriological Profile of Neonatal Sepsis in Neonatal Intermediate Care Unit of Central Paediatric Referral Hospital in Nepal. J Nepal Health Res Counc. 2015;13(31):205-8. [Pubmed]

21. Berhe $H$, Alemanyehu B, Ukbayohannes $R$, Getachew G. Menstrual Hygiene Practice and Associated Factors Among Adolescent High School Girls. JBiolnnov. 2016;5(1):1-15. [Full text]

22. Parmar A, Khanpara H, Kartha G. A study on taboos and misconceptions associated with pregnancy among rural women of Surendranagar district. healthline pISSN. 2013;4(2):2-5. [Full text]

23. Patil R, Mittal A, Vedapriya $D$, Khan MI, Raghavia M. Taboos and misconceptions about food during pregnancy among rural population of Pondicherry. Calicut Medical Journal. 2010;8(2):4-8. [Full text]

24. Kumar D, Goel NK, Sharma MK, Kaur G. Menstrual problems of school going unmarried adolescent girls and their treatment seeking behavior in Chandigarh, India. Int J Community Med Public Health. 2016;3(11):3106-16. [Full text]

25. Amatya P, Ghimire S, Callahan KE, Baral BK, Poudel $K C$. Practice and lived experience of menstrual exiles (Chhaupadi) among adolescent girls in far-western Nepal. PLoS ONE. 2018;13(12):1-17. https://doi.org/10.1371/journal.pone.0208260, [Full text]

26. Kumar GM, Kundan M. Psycho-Social Behaviour of Urban Indian Adolescent Girls during menstruation Department of Pediatrics, Pt . B . D . Sharma PGIMS, Rohtak. Australasian Medical Journal. 2011;4(1):49-52. [Full text]

27. Adinma ED. Perceptions and Practices on Menstruation. African Journal of Reproductive Health. 2008;12(1):74-83. [Full text] 